\title{
Effects of Straw Return and Feed Addition on the Environment and Nitrogen use Efficiency in the Rice-Crayfish System
}

\section{Pengli Yuan}

Huazhong Agricultural University

Mingli Ni

Huazhong Agricultural University

Cougui Cao

Huazhong Agricultural University

Ligeng Jiang

Guangxi University

Anas Iqbal

Guangxi University

Jinping Wang ( $\nabla$ wangjp@mail.hzau.edu.cn )

Huazhong Agricultural University

\section{Research Article}

Keywords: rice-crayfish model, nitrogen, $15 \mathrm{~N}$ isotope labeling, nitrogen use efficiency

Posted Date: December 6th, 2021

DOI: https://doi.org/10.21203/rs.3.rs-1089572/v1

License: () (1) This work is licensed under a Creative Commons Attribution 4.0 International License.

Read Full License 
1 Effects of straw return and feed addition on the environment and nitrogen

2 use efficiency in the rice-crayfish system

3 Pengli Yuan ${ }^{\mathrm{a}, \mathrm{b}}$, Mingli Ni ${ }^{\mathrm{a}}$,Cougui $\mathrm{Cao}^{\mathrm{a}}$, Ligeng Jiang ${ }^{\mathrm{b}}$, Anas Iqbal ${ }^{\mathrm{b}}$, Jinping Wang ${ }^{\mathrm{a},}$ *

$4 \quad{ }^{a}$ Laboratory of Crop Ecophysiology and Farming System in the Middle Reaches of Yangtze River,

5 College of Plant Science and Technology, Huazhong Agricultural University, Wuhan, Hubei

6430070 , China

$7 \quad{ }^{\mathrm{b}}$ Key Laboratory of Crop Cultivation and Farming Systems College of Agriculture, Guangxi

8 University, Nanning 530004, China.

9 *Corresponding author. E-mail address: wangjp@mail.hzau.edu.cn

10 Abstract

11 Purpose Understanding the direction of nitrogen flow in the ricecrayfish system (RC) and optimizing the rate of nitrogen fertilizer

13 application (ORN) are of great significance for sustainable development 14 of RC.

15 Methods To this end, a field experiment involving straw and feed treatment was conducted to delineate the flow of the nitrogen present in 17 the straw (straw-N) and feed (feed-N). Second, under different feed and straw treatments, we carried out a mesocosm experiment with different rates of ${ }^{15} \mathrm{~N}$-labeled nitrogen fertilizer application to explore the optimal rate under the effects of feed-N and straw-N supply.

21 Results The results showed that at $75 \mathrm{~kg} \mathrm{~N} \mathrm{ha}^{-1}(75 \mathrm{~N}), 14 \%$ and $1.86 \%$ 22 of feed-N and $4.3 \%$ and $8.78 \%$ of straw- $\mathrm{N}$ is absorbed by crayfish and 23 rice, respectively. The percentage of feed-N and straw-N lost to the 24 environment was the lowest at $75 \mathrm{~N}$, i.e., $84.48 \%$ and $86.92 \%$, 
respectively. Using straw return to the field and feeding as the basic management measures for $\mathrm{RC}$, we observed that the rice yield was the highest under $75 \mathrm{~N}$, and the highest nitrogen utilization efficiency (NUE) was $25 \%$, and the highest the percentage of soil storing nitrogen by the fertilizer-derived was $34 \%$ (lost to the environment, at least $41 \%$ ).

Conclusions ORN could help in the effective utilization of feed-N and straw-N via a compensation effect, promote the absorption and transport of nitrogen, and ultimately lead to an improvement in NUE in RC.

Keywords: rice-crayfish model, nitrogen, ${ }^{15} \mathrm{~N}$ isotope labeling, nitrogen use efficiency

\section{Abbreviations}

ORN optimizing the rate of nitrogen fertilizer application

SF Straw with feed

SN Straw with no feed

NF No straw with feed

NN No straw with no feed

0N 0 kg nitrogen ha ${ }^{-1}$

$75 \mathrm{~N} 75 \mathrm{~kg}$ nitrogen $\mathrm{ha}^{-1}$

$150 \mathrm{~N} \quad 150 \mathrm{~kg}$ nitrogen $\mathrm{ha}^{-1}$

$225 \mathrm{~N} 225 \mathrm{~kg}$ nitrogen $\mathrm{ha}^{-1}$

$\mathrm{N}_{\mathrm{dff}}(\%)$ the proportion of rice $\mathrm{N}$ derived from the fertilizer

NUE $(\%)$ percentage of fertilizer-derived $\mathrm{N}$ that was used by the rice 
$\mathrm{R}_{\text {soil }}(\%) \quad$ the percentage of fertilizer-derived $\mathrm{N}$ that was stored by the soil

$\mathrm{R}_{\text {loss }}(\%)$ represents the percentage of fertilizer-derived $\mathrm{N}$ lost to the environment

\section{Introduction}

Nitrogen is essential for crop growth, and it can promote food production (Xu et al., 2012; Yi et al., 2019). Therefore, the use of nitrogen fertilizers is a very important measure in farmland management for intensive agricultural production (Matson et al., 1997). Studies have shown that between 1982 and 2017, grain production in China increased by $74 \%$, while the use of chemical fertilizers tripled (Cui and Shoemaker, 2018). In China, the average nitrogen utilization efficiency (NUE) for crop production was estimated to be 0.25 , indicating that large amounts of nitrogen are lost to the environment (China National Statistics Bureau, 2018).

During crop production, the residual nitrogen fertilizer that is not absorbed by crops damages both the ecosystem and human health (Erisman et al., 2013). High levels of nitrogen fertilizer can directly or indirectly drive soil acidification (Matsuyama et al., 2005). Further, it has been found that during intensive agricultural production in China over an almost 30-year period, large amounts of nitrogen fertilizer have been 
added to a limited area of land. By the beginning of the $21^{\text {st }}$ century, the $\mathrm{pH}$ value of soil in China's main crop production areas had dropped significantly, and the soil had become acidified (Guo et al., 2010). Nitrogen fertilizers from rice fields and farmland water enter the surface runoff and groundwater and cause the eutrophication of water bodies (Chen et al., 2013). Residual nitrogen from fertilizers in rice fields also enters the atmosphere in the form of $\mathrm{N}_{2} \mathrm{O}$ after oxidation, increasing the greenhouse effect (Davidson 2009). Therefore, the management of nitrogen fertilizers in high-yield rice systems is critical.

The integrated rice cultivation model that was developed in China and subsequently used for thousands of years allows the effective control of nitrogen fertilizer use and can help improve nitrogen utilization in rice fields (Hu et al., 2016). This model involves agricultural rice production in combination with the breeding of fish, ducks, crayfish, turtles, or loaches (Hu et al., 2016). Studies have shown that the rice-fish system requires, on average, $19 \%$ less nitrogen fertilizer than the rice monoculture system (Xie et al., 2011). In the rice-duck system, ducks are active in the paddy field, and the intertillage effect is obvious. This effect can lead to the loosening of paddy soil, promote gas exchange, improve soil permeability, and improve the organic carbon, total nitrogen (TN), and available nitrogen levels in the soil (Li et al., 2008). It has been found that a duck can produce $10 \mathrm{~kg}$ of excrement during the rice-duck co- 
cropping period, equivalent to $47 \mathrm{~g}$ of nitrogen, $70 \mathrm{~g}$ of phosphorous, and $31 \mathrm{~g}$ of potassium, thus fertilizing the rice field (Zhao et al., 2005).

The rice-crayfish (RC) model is an integrated rice cultivation model that has emerged in the middle and lower Yangtze river region in recent years (Yuan et al., 2020a). There are several differences in farmland management measures between traditional local rice fields and $\mathrm{RC}$ fields (Si et al., 2017). In RC fields, in the non-rice season, the flooding depth of the field is adjusted to $0.5-1.0 \mathrm{~m}$ in order to promote the growth and development of crayfish (Yuan et al., 2020b). In order to grow the crayfish to commercial standards, a large amount of feed is added to the paddy field. After the rice is harvested, rice straw is returned to the field and the field is flooded. This flooding is maintained until June of the following year, before rice crops are planted again. In the rice-growing season, the management and cultivation of rice is performed in a manner similar to that used in local traditional rice fields.

Feed and straw input is closely related to the utilization efficiency of nitrogen fertilizers in the $\mathrm{RC}$ system. Owing to the shift from rice monoculture to the RC model, excess nutrients have accumulated in the soil and there have been negative effects on the environment (Hu et al., 2021). Research has shown that the amount of nitrogen fertilizer used by $\mathrm{RC}$ farmers in paddy fields is $150 \mathrm{~kg} \mathrm{~N} \mathrm{ha}^{-1}$ (Hu et al., 2021), but it is unclear if this value is optimal. While studies have explored the optimal 
113 nitrogen fertilizer application rate in the rice-fish system under feed 114 combinations that allow the best yield without causing environmental

115 pollution (Hu et al., 2013), such studies in the RC system are lacking.

116 Moreover, it is unclear whether rice production can be maintained while 117 preventing environmental pollution in a large-scale commercial RC 118 model.

119 Therefore, the overall aim of the present study was to identify the 120 optimal nitrogen fertilizer application rate in RC fields after straw and 121 feed addition. To this end, we conducted two experiments. In the field experiment, we compared the impact of the RC system on water bodies 123 and environmental changes under straw and feed treatment. In the 124 mesocosm experiment, we explored the utilization efficiency of the 125 nitrogen fertilizer in $\mathrm{RC}$ fields under different rates of nitrogen fertilizer application.

2. Materials and methods

2.1. Study site The field experiment was conducted at an experimental station in

131 Houhu Village, Qianjiang City, Hubei Province $\left(30^{\circ} 39^{\prime} \mathrm{N}, 112^{\circ} 71^{\prime}\right.$ E). The experimental site was located in the low-lying lake area of the Jianghan plain. This area has a north subtropical humid monsoon climate

134 with a mean long-term temperature of $16.1^{\circ} \mathrm{C}$ and had an annual 
precipitation of $1100 \mathrm{~mm}$ in 2018 (Fig. 1). The studied area had been under continuous paddy RC cultivation for at least 3 years before the experiment was started in 2018. The soil was fluvo-aquic paddy soil arising from lake sediments and had a $\mathrm{pH}$ level of 7.12. The total nitrogen content was $2.41 \mathrm{~g} \mathrm{~kg}^{-1}$ and the organic matter content was $26.43 \mathrm{~g} \mathrm{~kg}^{-1}$.

2.2. Experimental design

In order to explore the impact of straw return and feed addition on the environment in RC fields, we set up a two-factor experiment. There were four test treatments - (i) straw with feed (SF), (ii) straw with no feed (SN), (iii) no straw with feed (NF), and (iv) no straw with no feed (NN) — and each treatment was repeated thrice, yielding a 12 -test plot. The area of the rice plantation in each plot was $1000 \mathrm{~m}^{2}$. A ring-shaped ditch (2.0 $\mathrm{m}$ wide and $2.0 \mathrm{~m}$ deep) was dug around the rice-planting region for crayfish to live in, and a $0.4-\mathrm{m}$ high crayfish escape net was set outside the ring ditch.

In the non-rice season, straw was returned to the field using a harvester such that a low stubble remained. The straw was then crushed on the surface to cover the field. For the no-straw treatment, the straw was manually removed from the field after the rice harvest in 2017. In the cultivation system, we also used crayfish (Procambarus clarkii). Feed was added every afternoon from March 12 to June 1, but for the no-feed treatment, no additional feed was added. Crayfish were fed with 
commercial formula feed containing $4.6 \%$ nitrogen per day at about 17:00 throughout the experiment. The daily amount of feed added was about $1.5 \%$ of the fresh body mass of the crayfish in each plot, and this amount increased as the crayfish grew. Crayfish were harvested daily between March and June; adult crayfish were picked, and the juveniles were returned to the original community. The amount of straw returned to the field and the amount of feed added are shown in Table 2.

In the rice season, we used the rice variety Taiyou 390 (Oryza sativa $L)$. Three weeks after germination, rice seedlings were transferred to the test plots, with $25-\mathrm{cm}$ gaps between rows and 26-cm gaps between the hills (four seedlings per hill) within each row. In the paddy field, there were three replicates for each treatment. One replicate for each treatment was randomly selected for the ${ }^{15} \mathrm{~N}$ isotope tracer test to explore the optimal rate of nitrogen fertilizer application in the RC model. The following nitrogen application rates were used for each treatment: $0 \mathrm{~kg} \mathrm{~N}$ $\mathrm{ha}^{-1}(0 \mathrm{~N}), 75 \mathrm{~kg} \mathrm{~N} \mathrm{ha}^{-1}(75 \mathrm{~N}), 150 \mathrm{~kg} \mathrm{~N}^{-1}(150 \mathrm{~N}), 225 \mathrm{~kg} \mathrm{~N}^{-1}$ $(225 \mathrm{~N})$. Each treatment was repeated thrice, yielding a total of 60 test micro areas wherein the ${ }^{15} \mathrm{~N}$ isotope experiment was conducted. ${ }^{15} \mathrm{~N}$ labeled urea produced by Shanghai Research Institute of Chemical Industry was used as the nitrogen fertilizer, and the ${ }^{15} \mathrm{~N}$ abundance was $10.28 \%$. Base fertilizer and tiller fertilizer containing nitrogen were applied at a 1:1 ratio. After the surface water in the RC fields receded, but 
before rice crops were planted, a round PVC pipe with a diameter of 0.4 $\mathrm{m}$ and height of $0.4 \mathrm{~m}$ was inserted $0.4 \mathrm{~m}$ underground. Further, $0.2 \mathrm{~m}$ of the pipe was kept above the ground to prevent the loss of ${ }^{15} \mathrm{~N}$ and the entry of external N. A $0.5-\mathrm{cm}$ hole was drilled in the PVC pipe $20 \mathrm{~cm}$ above the surface of the field. When the water level in the micro area dropped to the field surface, the field surface water flowed into the micro area as replenishment. While fertilizer was added, the hole was blocked with mud to prevent fertilizer loss in the micro area. During the growth period, other management measures such as pest control were implemented uniformly across treatment plots.

\subsection{Plant and soil sampling and analysis}

We collected 0-20 cm of the cultivated soil layer and stored it as fresh wet soil and natural air-dried dry soil. For the experiment, $1 \mathrm{~g}$ of $0.15 \mathrm{~mm}$ dry soil was obtained and concentrated sulfuric acid was added for digestion. The determination of soil bulk density was performed using the ring knife method. In the experiment, all the above-ground rice plants in the micro area were collected after rice growth was complete. The stems, leaves, and panicles were separated, heated at $105^{\circ} \mathrm{C}$ for $0.5 \mathrm{~h}$, and then dried in an oven at $80^{\circ} \mathrm{C}$ until they reached constant weight. Rice plant samples that were ground and dried to a constant weight were $0.15 \mathrm{~mm}$ in diameter. The soil samples and dried plants were ground with a ball mill and wrapped separately into balls with tin foil. The isotopic abundance 
was measured using a stable isotope mass spectrometer (IsoPrime 100

IRMS, Isoprime Ltd, Stockport, UK).

During the feeding period, 15 crayfish were randomly selected from among the crayfish caught from each plot and dried at $80^{\circ} \mathrm{C}$ until they reached constant weight. The TN content of the rice plants, crayfish feed, and straw were obtained separately using a $\mathrm{C} / \mathrm{N}$ analyzer (Vario MAXCN elemental analyzer, Germany).

2.4. Data analysis

\subsubsection{Analysis of nitrogen balance}

The balance of nitrogen output and input within the RC fields was

211 calculated by subtracting the TN output (nitrogen present in harvested plants and crayfish) from the total input (nitrogen present in fertilizers, crayfish feed, and straw). A positive value indicated that some portion of the input nitrogen had not been used by rice and crayfish and remained in

215 the field plot (as nitrogen in the soil or water) or had moved into the surrounding environment (as nitrogen in the atmosphere or drainage water).

2.4.2 Analysis of the fate of the nitrogen derived from crayfish feed and

219 straw

In fields subjected to $\mathrm{NN}$ treatment (no crayfish feed or rice straw application), the nitrogen in crayfish (crayfish N) was derived from the

222 environment only and the nitrogen in rice plants (rice $\mathrm{N}$ ) was derived 
from fertilizers and the environment. In fields subjected to NF treatment

224 (crayfish feed and no straw application), crayfish $\mathrm{N}$ was derived from

225 crayfish feed and the environment, and rice $\mathrm{N}$ was derived from fish feed,

226 fertilizers, and the environment. In fields subjected to SN treatment, 227 crayfish $\mathrm{N}$ was derived from straw and the environment, and rice $\mathrm{N}$ was

228 derived from straw, fertilizers, and the environment. To understand the

229 fate of the crayfish- and straw-derived nitrogen in the RC system, we

230 performed eight calculations, which included the following variables:

$231 \mathrm{X}_{\mathrm{SN}}$, nitrogen input through straw under the SN treatment;

$232 \mathrm{X}_{\mathrm{NF}}$, nitrogen input through feed under the NF treatment;

$233 \quad$ crayfish $_{\mathrm{SN}}-\mathrm{N}$, crayfish $\mathrm{N}$ under the $\mathrm{SN}$ treatment;

$234 \quad$ rice $_{\mathrm{SN}}-\mathrm{N}$, rice $\mathrm{N}$ under the $\mathrm{SN}$ treatment;

235 crayfish $_{\mathrm{NF}}-\mathrm{N}$, crayfish $\mathrm{N}$ under the NF treatment;

$236 \quad$ rice $_{\mathrm{NF}}-\mathrm{N}$, rice $\mathrm{N}$ under the $\mathrm{NF}$ treatment;

$237 \quad$ fish $_{\mathrm{NN}}-\mathrm{N}$, crayfish $\mathrm{N}$ under the $\mathrm{NN}$ treatment;

$238 \quad$ rice $_{\mathrm{NN}}-\mathrm{N}$, rice $\mathrm{N}$ under the $\mathrm{NN}$ treatment;

$239 \quad \mathrm{FX}_{\mathrm{NF}}$, crayfish $\mathrm{N}$ derived from crayfish feed under the NF treatment;

$240 \quad \mathrm{RX}_{\mathrm{NF}}$, rice $\mathrm{N}$ derived from crayfish feed under the NF treatment;

$241 \quad \mathrm{FX}_{\mathrm{SN}}$, crayfish $\mathrm{N}$ derived from straw under the SN treatment;

$242 \mathrm{RX}_{\mathrm{SN}}$, rice $\mathrm{N}$ derived from straw under the $\mathrm{SN}$ treatment;

$243(\%) \mathrm{FX}_{\mathrm{NF}}$, percentage of total crayfish feed-derived nitrogen incorporated

244 into the crayfish biomass under the NF treatment; 
(\%) $\mathrm{RX}_{\mathrm{NF}}$, percentage of total crayfish feed-derived nitrogen

246 incorporated into the rice biomass under the NF treatment;

$247 \quad(\%)$ environment NF, percentage of total crayfish feed-derived nitrogen

248 remaining in the environment under the NF treatment;

249 (\%) $\mathrm{FX}_{\mathrm{SN}}$, percentage of total straw-derived nitrogen incorporated into

250 the crayfish biomass under the NF treatment;

251 (\%) $\mathrm{RX}_{\mathrm{SN}}$, percentage of total straw-derived nitrogen incorporated into

252 the rice biomass under the NF treatment;

253 (\%) environment SN, percentage of total straw-derived nitrogen

254 remaining in the environment under the NF treatment.

255 The calculations were performed as follows:

$\mathrm{FX}_{\mathrm{NF} \text { or SN}}=\left(\right.$ crayfish $\left._{\mathrm{NF} \text { or SN }}-\mathrm{N}\right)-\left(\right.$ crayfish $\left._{\mathrm{NN}}-\mathrm{N}\right)$

$256 \mathrm{RX}_{\mathrm{NF} \text { or SN}}=\left(\right.$ rice $\left._{\mathrm{NF} \text { or SN}}-\mathrm{N}\right)-\left(\right.$ rice $\left._{\mathrm{NN}}-\mathrm{N}\right)$

$257 \quad)$

$258(\%) \mathrm{FX}_{\mathrm{NF} \text { or SN }}=\left(\mathrm{FX}_{\mathrm{NF} \text { or SN }} / \mathrm{X}_{\mathrm{NF} \text { or SN }}\right) \times 100$

$259 \quad)$

$260(\%) \mathrm{RX}_{\mathrm{NF} \text { or SN}}=\left(\mathrm{RX}_{\mathrm{NF} \text { or SN }} \mathrm{X}_{\mathrm{NF} \text { or SN }}\right) \times 100$

(\%)environment $\mathrm{NF}$ or $\mathrm{SN}=\frac{\left(\mathrm{X}_{\mathrm{NF} \text { or SN }}-\mathrm{FX}_{\mathrm{NF} \text { or SN}}-\mathrm{RX}_{\mathrm{NF} \text { or SN }}\right)}{\mathrm{X}_{\mathrm{NF} \text { or SN }}} \times 100$

2.4.3 Stable isotope analysis

Stable isotope values were reported in $\delta$ notation: 


$$
\delta^{15} \mathrm{~N}=\left(\frac{\mathrm{R}_{\text {sample }}}{\mathrm{R}_{\text {standard }}}-1\right) \times 1000
$$

Where $\mathrm{R}$ is ${ }^{15} \mathrm{~N} /{ }^{14} \mathrm{~N}$, and the standard sample used for determining ${ }^{15} \mathrm{~N}$ concentration is $\mathrm{N}_{2}$ from the air $\left({ }^{15} \mathrm{~N}=0.003676\right)$. or total soil nitrogen was calculated as follows:

$$
\mathrm{N}_{\text {dff }}(\%)=\frac{\left(\delta^{15} \mathrm{~N}_{\text {sample }}-\delta^{15} \mathrm{~N}_{0}\right)}{\left(\delta^{15} \mathrm{~N}_{\text {fertilizer }}-\delta^{15} \mathrm{~N}_{\text {nature }}\right)} \times 100
$$

where $\mathrm{N}_{\mathrm{dff}}(\%)$ represents the proportion of rice $\mathrm{N}$ derived from the

272 fertilizer. ${ }^{15} \mathrm{~N}_{\text {sample }},{ }^{15} \mathrm{~N}_{0},{ }^{15} \mathrm{~N}_{\text {fertilizer, }}$, and ${ }^{15} \mathrm{~N}_{\text {nature }}$ represent the plant sample, $0 \mathrm{~kg} \mathrm{~N} \mathrm{ha}{ }^{-1}$ treatment sample, fertilizer, and natural abundance value in the mesocosms, respectively.

We estimated the percentage of fertilizer-derived nitrogen that was used by the rice as follows:

$\operatorname{NUE}(\%)=\frac{\mathrm{N}_{\text {rice }} \times \mathrm{N}_{\text {dff }}}{\mathrm{N}_{\text {fertilizer }}}$

277 where $\mathrm{N}_{\text {rice }}$ is the total rice biomass- $\mathrm{N}$ and $\mathrm{N}_{\text {fertilizer }}$ is total fertilizer- $\mathrm{N}$ 278 in the mesocosms experiment.

279 We estimated the percentage of fertilizer-derived nitrogen that was 280 stored by the soil as follows:

$$
\mathrm{R}_{\text {soil }}(\%)=\frac{\left(\mathrm{N}_{\mathrm{dff}} \times \mathrm{H} \times \mathrm{BD} \times \mathrm{TN}_{\text {soil }}\right)}{\mathrm{N}_{\text {fertilizer }}} \times 10
$$

282 where $\mathrm{N}_{\text {dff }}$ is the percentage of fertilizer-derived nitrogen in the soil. The

$\mathrm{H}$ value is 20 , representing the thickness of the soil layer $(\mathrm{cm})$. BD is soil 
284 bulk density $\left(\mathrm{g} \mathrm{cm}^{3}\right)$, and $\mathrm{TN}_{\text {soil }}$ is the $\mathrm{TN}$ content of the soil $\left(\mathrm{g} \mathrm{kg}^{-1}\right)$.

$285 \mathrm{~N}_{\text {fertilizer }}$ is ${ }^{15} \mathrm{~N}$-labeled urea nitrogen content $\left(\mathrm{kg} \mathrm{ha}^{-1}\right)$ and the 10 is for unit 286 conversion.

$\mathrm{R}_{\text {loss }}(\%)=100-\mathrm{NUE}(\%)-\mathrm{R}_{\text {soil }}(\%)$ where $R_{\text {loss }}(\%)$ represents the percentage of fertilizer-derived nitrogen

lost to the environment.

2.4.4 Statistical analysis

All statistical analyses were performed using SPSS 22.0 (SPSS, Inc.,

USA). One-way analysis of variance (ANOVA) at $\alpha=0.05$ probability

was conducted to test the significance of differences across different treatments, and if significance was observed via ANOVA, an LSD test was used to compare means. OriginPro 9.0 was used to prepare all graphs.

\section{Results}

3.1 Rice aboveground biomass, yield, ${ }^{15} \mathrm{~N}$ natural abundance, and nitrogen content of the rice fractions

During NF treatment, the rice stem biomass under $225 \mathrm{~N}$ was significantly higher than that under $0 \mathrm{~N}(p<0.05)$, but there was no significant difference between the values at $75 \mathrm{~N}$ and $150 \mathrm{~N}$ (Table 2). application was significantly higher than that under $225 \mathrm{~N}$ and $0 \mathrm{~N}$ 
application $(p<0.05)$ (Table 2). There was no significant difference in rice

307 yield between $75 \mathrm{~N}$ and $150 \mathrm{~N}$ application (Table 2).

Under different nitrogen rates, the natural abundance of ${ }^{15} \mathrm{~N}\left(\delta^{15} \mathrm{~N}\right)$ in the fractions of rice was significantly different $(p<0.05)$; it was the highest under $225 \mathrm{~N}$, followed by $150 \mathrm{~N}, 75 \mathrm{~N}$, and $0 \mathrm{~N}$ (Table 3). During

311 NN, SF, and SN treatment, there was no significant difference in nitrogen

312 content in the fraction of rice at different nitrogen rates (Table 3). During

$313 \mathrm{NF}$ treatment, at $225 \mathrm{~N}$, the nitrogen content in the leaves was 314 significantly higher than that at $150 \mathrm{~N}, 75 \mathrm{~N}$, and $0 \mathrm{~N}(p<0.05)$. However, 315 there was no significant difference in grain nitrogen content under 316 different nitrogen rates (Table 3).

The yield of crayfish under SF and NF treatments was significantly higher than that under NN and SN treatments (Table 4) $(p<0.05)$. The 320 yield of crayfish in $\mathrm{SN}$ was significantly higher than that in $\mathrm{NN}(p<0.05)$. Although there was no significant difference in crayfish production between SF and NF, the crayfish production with SF treatment was $9 \%$ higher than that with NF treatment (Table 4). The nitrogen accumulation 324 in crayfish under SF and NF treatments was also significantly higher than that under NN and SN treatments $(p<0.05)$ (Table 4$)$. The crayfish yield was therefore mainly affected by feed input. 
After one year of RC co-culturing, the total nitrogen content of the soil did not differ significantly under different nitrogen rates in the NN,

SF, SN, and NF treatments (Table 5). However, the ${ }^{15} \mathrm{~N}$ content of the soil in each treatment increased significantly with an increase in nitrogen rate $(225 \mathrm{~N}>150 \mathrm{~N}>75 \mathrm{~N})(p<0.05)$. Under $75 \mathrm{~N}, 150 \mathrm{~N}$, and $225 \mathrm{~N}$ nitrogen rates, the total nitrogen content of the soil during $\mathrm{SF}, \mathrm{SN}$, and NF treatments was significantly higher than that during NN treatment (Table 5) $(p<0.05)$.

\subsection{Nitrogen use efficiency in RC}

3.4.1 Efficiency of straw- and feed-derived nitrogen use

We calculated the utilization rate of straw and feed nitrogen in the RC system using the subtraction method (Xie et al., 2011). Under the $0 \mathrm{~N}$, $150 \mathrm{~N}$, and $225 \mathrm{~N}$ treatments, $13.66 \%$ of feed nitrogen was absorbed by the crayfish and the remaining $86.34 \%$ was lost to the environment (Fig. 2a, c, d). However, under a nitrogen application rate of $75 \mathrm{~N}, 1.86 \%$ of the feed nitrogen was absorbed by the rice, and the loss of feed nitrogen to the environment was reduced to $84.48 \%$ (Fig. $2 \mathrm{~b}$ ).

Under different rates of nitrogen application, $4.3 \%$ of straw nitrogen was absorbed by crayfish (Fig. 2). However, under the $0 \mathrm{~N}, 75 \mathrm{~N}, 150 \mathrm{~N}$, and $225 \mathrm{~N}$ treatment, $10.33 \%, 8.78 \%, 8.15 \%$, and $0 \%$ of straw nitrogen was absorbed by the rice, respectively (Fig. 2a, b, c, d). With the increase

349 in nitrogen rates, the amount of straw nitrogen lost to the environment 
increased (Fig. 2).

\subsubsection{Efficiency of fertilizer-derived nitrogen use}

Under NN, SF, NF, and SN treatments, the percentage of fertilizerderived nitrogen in rice stems, leaves, and grains $\left(\mathrm{N}_{\mathrm{dff}}\right)$ increased significantly with the increase in nitrogen application rates $(p<0.05)$ (Table 6). As shown by the nitrogen distribution pattern (Table 6), the nitrogen uptake by grains was significantly higher than that by rice stems and leaves. Under SF treatment, panicles accounted for $65.1 \%, 66.8 \%$, and $62.4 \%$ of the total nitrogen uptake at application rates of $75 \mathrm{~N}, 150 \mathrm{~N}$, and $225 \mathrm{~N}$, respectively.

There was no significant difference in the NUE of rice stems and leaves across nitrogen levels under each treatment (Table 6). Under NN and SF treatments, the NUE of rice panicles at application rates of $75 \mathrm{~N}$ and $150 \mathrm{~N}$ was significantly higher than that at $225 \mathrm{~N}(p<0.05)$ (Table 6). However, there was no significant difference in NUE between the $75 \mathrm{~N}$ and $150 \mathrm{~N}$ rates. Although the NUE of rice panicles at $150 \mathrm{~N}$ was significantly higher than that at $75 \mathrm{~N}$ and $225 \mathrm{~N}$ under the $\mathrm{SN}$ treatment $(p<0.05)$, there was no significant difference between the values at $75 \mathrm{~N}$ and $150 \mathrm{~N}$.

The application of chemical nitrogen fertilizers significantly increases food production. However, not all the nitrogen fertilizer added to agricultural fields remains available for crop nourishment — some is 
absorbed by the crop, some is stored in the soil, some is discharged into the atmosphere in gaseous form, and some is lost to water bodies due to rainfall and irrigation. Nitrogen gas is discharged into the atmosphere, intensifying the greenhouse effect and accelerating global warming. The addition of nitrogen to surface water bodies, especially those receiving return flow from the agricultural farmland in the irrigation region, can lead to eutrophication.

The flow of nitrogen at different nitrogen fertilizer application rates under different straw and feed treatments in RC fields is shown in Figure 3. The storage of fertilizer nitrogen in the soil (Rsoil(\%)) was calculated using formula 9 and the soil bulk density value (Table 7) (Fig. 3). In the SF and NF treatments, the Rsoil(\%) value under the $75 \mathrm{~N}$ nitrogen rate was significantly higher than that under the $150 \mathrm{~N}$ and $225 \mathrm{~N}$ treatments $(p<0.05)$. Under SF treatment, the amount of nitrogen fertilizer stored in the soil and rice plants at application rates of $75 \mathrm{~N}, 150 \mathrm{~N}$, and $225 \mathrm{~N}$ was $44 \mathrm{~kg} \mathrm{ha}^{-1}, 72 \mathrm{~kg} \mathrm{ha}^{-1}$, and $88 \mathrm{~kg} \mathrm{ha}^{-1}$, respectively. The nitrogen not accounted for in the rice plant and soil was presumably lost; therefore, under SF treatment, the rates at which ${ }^{15} \mathrm{~N}$ was lost were $41 \%, 52 \%$, and $61 \%$ at application rates of $75 \mathrm{~N}, 150 \mathrm{~N}$, and $225 \mathrm{~N}$, respectively. The amount of nitrogen recovered increased and the rate of loss increased when more nitrogen fertilizer was added to the fields. When fertilizer application was reduced to $75 \mathrm{~N}$, nitrogen uptake by rice plants and soil 
reduced to $43 \mathrm{~kg} \mathrm{ha}^{-1}, 44 \mathrm{~kg} \mathrm{ha}^{-1}$, and $40 \mathrm{~kg} \mathrm{ha}^{-1}$ under NN, SF, and NF treatments, respectively, but the loss rate $(\mathrm{R} \operatorname{loss}(\%))$ significantly reduced too, reaching $43 \%, 41 \%$, and $46 \%(p<0.05)$, respectively. Although, Rloss treatments than in the NN and SN treatments (Fig. 4) $(p<0.04)$. was $66 \%, 66 \%$, and $62 \%$, respectively, there was no significant difference in the nitrogen levels across micro areas with these application rates.

\subsubsection{Nitrogen storage in the RC system}

With the increase in the nitrogen rate, the nitrogen storage in rice grains increased slightly under the NN, SF, SN, and NF treatments, but the differences were not significant (Fig. 4). Under different nitrogen rates, the nitrogen accumulation in crayfish was significantly higher under SF and NF treatments than under NN and SN treatments $(p<0.05)$. Under $0 \mathrm{~N}$, the rice and crayfish in the RC system could absorb 2 and 1.5 $\mathrm{kg} \mathrm{N} \mathrm{ha}^{-1}$ from the environment $\mathrm{NN}$ and $\mathrm{SN}$ treatment, respectively (Fig. 4a). However, under SF and NF treatment, $60 \mathrm{~kg} \mathrm{ha}^{-1}$ and $30 \mathrm{~kg} \mathrm{ha}^{-1}$ of nitrogen was released into the environment, respectively. With the increase in the amount of nitrogen fertilizer, the nitrogen released into the environment in the $\mathrm{RC}$ system under treatments of returning straw to the field and feeding increased. Under differ nitrogen fertilizer rates, the storage capacity for nitrogen was significantly higher in the SF and NF 


\section{Discussion}

Our results showed that the yield of crayfish under feeding conditions (SF and NF) was significantly higher than that under no feeding conditions ( $\mathrm{SN}$ and $\mathrm{NN}$ ). As the direct food source for crayfish, feed can effectively promote their growth (Mukherjee et al., 2010; Naseem et al., 2020). Interestingly, our research found that the yield of crayfish in the SF condition was $13 \%$ higher than that in the NF condition, and the value in the $\mathrm{SN}$ condition was $2.3 \%$ higher than that in the NN condition (Table 4). Returning straw to the field increases the production of crayfish. During the non-rice season, crayfish can feed on rotten straw and microorganisms in order to obtain nutrients (Chien and Avault, 1983; Brown et al., 1990). Crayfish feed on straw, which accelerates the decomposition of straw owing to the over-abdominal effect, promotes the accumulation of organic matter in the paddy soil, and improves the fertility of the paddy soil (Yuan et al., 2020).

Under SF and NF conditions, $75 \mathrm{~N}$ and $150 \mathrm{~N}$ treatments provided the highest rice yield, and there was no significant difference in rice yield between $75 \mathrm{~N}$ and $150 \mathrm{~N}$ treatment (Table 2). However, in the $\mathrm{SN}$ condition, the Rloss(\%) under $150 \mathrm{~N}$ and $75 \mathrm{~N}$ nitrogen application rates was $41 \%$ and $52 \%$, respectively, with a significant difference between the values (Fig. 3). Although under the NF condition, the Rloss(\%) was not significantly different between $75 \mathrm{~N}$ and $150 \mathrm{~N}$, the Rloss( $\%)$ at $150 \mathrm{~N}$ was 
$15 \%$ higher than that at $75 \mathrm{~N}$ (Fig. 3). Under the SF condition, although the dry matter accumulation in rice stems and leaves was the highest at an application rate of $225 \mathrm{~N}$, the dry matter in the grains was the lowest (Table 2). Further, the total nitrogen accumulation in the stems, leaves, and grains was the lowest under SF treatment (Fig. 4). The excessive use of nitrogen fertilizers can make rice stems and leaves flourish but reduce the overall efficiency, resulting in insufficient grains and poor maturity of rice plants (Yang et al., 2018). The application of high-nitrogen fertilizers results in an increase in pests and diseases in rice fields and reduces rice yields (Bowling, 1963; Prabhu et al., 1996; Slaton et al., 2003). In the paddy field, rice plants can use the feed nitrogen that is not consumed by animals, as well as the ammonia that is excreted by fish and prawns (Mirhaj et al., 2014). In the RC system, feed nitrogen is a supplementary nitrogen source that can be used by rice, and therefore, the application of nitrogen fertilizer can be reduced. Our research shows that rice plants can use $13.66 \%$ and $4.3 \%$ of feed-N and straw-N in the RC system, respectively (Fig. 2). In the rice-fish system, rice plants can absorb $31.8 \%$ of feed-N, and the rice yield increases (Xie et al., 2011). Therefore, rice yield can be maintained with the application rate of $75 \mathrm{~N}$, and we suggest that nitrogen fertilizer application should be reduced in the RC system.

Aquaculture provides protein for human nutrition (Nissa et al., 2021), but the eutrophication and environmental pollution caused by intensive 
aquaculture production are widespread (Herbeck et al., 2013; Bian et al., 2012). The eutrophication of water bodies during intensive aquaculture is mainly caused by the nitrogen and phosphorus from unconsumed feed (Cantas and Yildirim., 2019). Combining the breeding of aquatic animals with the cultivation of rice can effectively promote the recycling and utilization of materials in the paddy field (Xie et al., 2011; Zhang et al., 2016). In the RC system, feed-N and straw-N can not only be absorbed by crayfish but can also be absorbed and utilized by rice, effectively promoting the nitrogen use efficiency.

In the RC system, due to the replenishment of feed-N and straw-N, the threshold of fertilizer nitrogen application during rice planting should be lower than the conventional application rate used by local farmers. Compared with the nitrogen application levels of $150 \mathrm{~N}$ and $225 \mathrm{~N}$, the nitrogen content of rice plants and crayfish under the $75 \mathrm{~N}$ treatment was higher. With the increase in the nitrogen application rate, the nitrogen content in rice plants and crayfish did not increase significantly, but the nitrogen levels in the environment did (Fig. 4). The unreasonable application of nitrogen fertilizer in the RC system causes economic losses and also increases the risk of non-point source pollution in the rice field (Hu et al., 2021). A reasonable amount of nitrogen fertilizer should be used in conjunction with straw return to the field and feeding treatment to ensure a high yield of rice, while improving the nitrogen use efficiency in 
the RC system, effectively reducing environmental pollution. This can provide a win-win situation in RC culture during the production process.

\section{Conclusion}

Integrating intensive crayfish culture with rice culture can allow for the procurement of substantial crayfish yields and stable rice yields. Straw and feed addition increase the nitrogen input in the RC system. The part of the feed-derived nitrogen that is not consumed by the crayfish can be absorbed by rice plants, and part of the straw-derived nitrogen can also be absorbed by rice plants and crayfish. Our research shows that under the RC model, with field management measures such as straw return to the field and feeding, the amount of nitrogen fertilizer used in the rice season should be controlled and maintained under $75 \mathrm{~kg} \mathrm{ha}^{-1}$. This will not only ensure a good rice yield but also reduce the accumulation of feed-N, straw-N, and fertilizer- $\mathrm{N}$ in the environment, thus reducing the potential for RC culture-induced environmental pollution during the production process.

\section{Acknowledgements}

This research was special fund for basics cientific research operation fees of central universities (2662019FW010 and 266202KPY014). 
Funding: The authors declare that no funds, grants, or other support were received during the preparation of this manuscript.

Competing Interests: The authors have no relevant financial or nonfinancial interests to disclose.

Author Contributions: Pengli Yuan: Conceptualization, design, data collection, Writing, Revision. Mingli Ni: Material preparation. Cougui

Cao: Supervision. Ligeng Jiang: Writing - review. Anas Iqbal: Editing. Jinping Wang: Experiment design.

Data availability: The datasets generated during and/or analysed during the current study are available from the corresponding author on reasonable request.

\section{References}

Bian W, Wang LG, Zhang HZ, Wang JF, Tian ZF, Chen XY (2012) Study on phosphorus pollution load of aquaculture in baiyangdian lake. Advanced Materials Research, 518-523, 14061411. https://doi.org/10.4028/www.scientific.net/AMR.518-523.1406.

Bowling CC (1963) Effect of nitrogen levels on rice water weevil populations. Journal of Economic Entomology, 56(6), 826-827. https://doi.org/10.1093/jee/56.6.826.

Brown PB, Hooe ML, Blythe WG (1990) Preliminary evaluation of production systems and forages for culture of orconectes virilis, the northern or fantail crayfish. Journal of the World Aquaculture Society, 21(1). 10.1111/j.1749-7345.1990.tb00953.x.

Cantas IB, Yildirim O (2019) Reducing the impact of feeds on the environment in sustainable aquaculture. Ege Journal of Fisheries and Aquatic Sciences, 36(1), 87-97. 10.12714/egejfas.2019.36.1.12. 
Chen SK, Jang CS, Chen SM, Chen KH (2013) Effect of N-fertilizer application on return flow water quality from a terraced paddy field in Northern Taiwan. Paddy and water environment,11(1), 123-133. https://doi.org/ 10.1007/s10333-011-0298-7.

Chien YH, Avault W (1983) Effects of flooding dates and disposals of rice straw on crayfish, Procambarus clarkii (Girard), culture in rice fields. Aquaculture, 31(2-4):339-359. 10.1016/00448486(83)90324-1

China National Statistics Bureau. China Population \& Employment Statistic Yearbooks (China Statistics Press, Beijing, China, 2000-2016).

Cui K, Shoemaker SP (2018) A look at food security in china. npj Science of Food, 2(1). https://doi.org/10.1038/s41538-018-0012-x.

Davidson EA (2009) The contribution of manure and fertilizer nitrogen to atmospheric nitrous oxide since 1860. Nature geoscience, 2(9):659-662. https://doi.org/10.1038/NGEO608.

Eladel H, Abd-Elhay R, Anees D (2019) Effect of rice straw application on water quality and microalgal flora in fish ponds. Egyptian journal of botany, 59(1), 171-184. http://doi.org/10.21608/ejbo.2018.4852.1199.

Erisman JW, Galloway JN, Seitzinger S, Bleeker A, Dise NB, Petrescu AMR, Leach AM, Devries, W (2013) Consequences of human modification of the global nitrogen cycle. Phil Trans R Soc B 368: 20130116. http://dx.doi.org/10.1098/rstb.2013.0116

Guo JH, Liu XJ, Zhang Y, Shen JL, Han WX, Zhang WF, Christie P, Goulding KWT, Vitousek P M, Zhang FS (2010) Significant acidification in major Chinese croplands. Science, 327,10081010. http://dx.doi.org/10.1126/science.1182570.

Herbeck LS, Unger D, Wu Y, Jennerjahn TC (2013) Effluent, nutrient and organic matter export from shrimp and fish ponds causing eutrophication in coastal and back-reef waters of ne hainan, tropical china. Continental Shelf Research, 57, 92-104. 10.1016/j.csr.2012.05.006.

Hou PF, Li GH, Wang SH, Jin X, Yang YY, Chen XT, Ding CQ (2013) Methane emissions from rice fields under continuous straw return in the middle-lower reaches of the Yangtze River. Journal of Environmental Sciences, 25(9):1874-1881. http://dx.doi.org/10.1016/S1001-0742(12)60273-3.

Hou J, Zhang DY, Zhu JQ (2021) Nutrient accumulation from excessive nutrient surplus caused by shifting from rice monoculture to rice-crayfish rotation. Environmental Pollution, 271:116367. https://doi.org/10.1016/j.envpol.2020.116367.

Hu LL, Ren WZ, Tang JJ, Li NN, Zhang J, Chen X (2013) The productivity of traditional ricefish co-culture can be increased without increasing nitrogen loss to the environment. Agriculture Ecosystems \& Environment, 177, 28-34. http://dx.doi.org/10.1016/j.agee.2013.05.023.

Hu LL, Zhang J, Ren WZ, Guo L, Cheng YX, Li JY, Li KX, Zhu ZW, Zhang JE, Luo SM, Cheng L, Tang JJ, Chen X (2016) Can the co-cultivation of rice and fish help sustain rice 
production?. Scientific reports, 6, 28728. https://doi.org/10.1038/srep28728.

Hu NJ, Liu CH, Chen Q, Zhu LQ (2021) Life cycle environmental impact assessment of ricecrayfish integrated system: a case study. Journal of Cleaner Production, 280,102444. https://doi.org/10.1016/j.jclepro.2020.124440

Li CF, Cao CG, Wang JP, Zhan M, Yuan WL, Ahmad S (2008) Nitrogen losses from integrated rice-duck and rice-fish ecosystems in southern China. 307(1-2):207-217. http://dio.org/10.1007/s11104-008-9597-1.

Matson PA, Parton WJ, Power AG, Swift MJ (1997) Agricultural intensification and ecosystem properties. Science, 277(5325), 504-509. http://dx.doi.org/10.1126/science.277.5325.504.

Matsuyama N, Saigusa M, Sakaiya E, Tamakawa K, Oyamada Z, Kudo K (2005) Acidification and soil productivity of allophanic Andosols affected by heavy application of fertilizers. Soil science and plant nutrition, 51(1):117-123. http://doi.org/10.1111/j.1747-0765.2005.tb00014.x.

Mirhaj M, Razzak MA, Wahab MA (2014) Comparison of nitrogen balances and efficiencies in rice cum prawn vs. rice cum fish cultures in Mymensingh, North-Eastern Bangladesh. Agricultural Systems, 125, 54-62. http://dx.doi.org/10.1016/j.agsy.2013.12.004.

Mukherjee AK, Kalita P, Unni BG, Wann SB, Saika D, Mukhpadhyay PK (2010) Fatty acid composition of four potential aquatic weeds and their possible use as fish-feed nutraceuticals. Food Chemistry 123: 1252-1254. 10.1016/j. foodchem.2010.05.057.

Naseem S, Bhat SU, Gani A, Bhat FA (2020) Perspectives on utilization of macrophytes as feed ingredient for fish in future aquaculture. Reviews in Aquaculture, 1-19. 10.1111/raq.12475.

Nissa MU, Pinto N, Parkar H, Goswami M (2021) Proteomics in fisheries and aquaculture: an $\begin{array}{lllll}\text { approach for food security. Food } & \text { Control, } & \text { 127:108125. }\end{array}$ https://doi.org/10.1016/j.foodcont.2021.108125.

Prabhu AS, Filippi MC, Zimmerman F (1996) Genetic control of blast in relation to nitrogen fertilization in upland rice. Pesquisa Agropecuária Brasileira, 31(5), 339-347. http://doi.org/ 10.1002/(SICI)1097-0010(199605)71:1<137::AID-JSFA563>3.0.CO;2-Y.

Si GH, Peng CL, Yuan JF, Xu XY, Zhao SJ, Xu DB, Wu JS (2017) Changes in soil microbial community composition and organic carbon fractions in an integrated rice-crayfish farming system in subtropical China. Sci. Rep., 7: 2856. http://doi.org/10.1038/s41598-017-02984-7.

Slaton NA, Cartwright RD, Meng J, Gbur EE, Norman RJ (2003) Sheath blight severity and rice yield as affected by nitrogen fertilizer rate, application method, and fungicide. Agronomy Journal, 95(6), 1489-1496. http://doi.org/10.2134/agronj2003.1489.

Xie J, Hu LL, Tang JJ, Wu X, Li NN, Yuan YG, Yang HS, Zhang JE, Luo SM, Chen X (2011) Ecological mechanisms underlying the sustainability of the agricultural heritage rice-fish coculture system. Proc Natl Acad Sci USA, 108(50):1381-1387. http://doi.org/10.1073/pnas.1111043108. 
Wang QX, Li ML, Chen XJ, Su Y, Yu M, Shen AL (2020) Effects of nitrogen management in soil microbial community structure at different growth stage under straw returning in paddy soils. Chinese Journal of Applied Ecology, 31(03),935-944 http://doi.org/10.13287/j.10019332.202003.027.

Xu GH, Fan XR, Anthony JM (2012) Plant nitrogen assimilation and use efficiency. Annual Review of Plant Biology, 63(1), 153-182. http://doi.org/10.1146/annurev-arplant-042811-105532.

Yang GT, Wang XC, Peng YL, Rasul F, Zou T, Hu YG (2018) Different micro-climate response of indica rice populationÂ to nitrogen fertilizer. Plant, Soil and Environment, 64(No. 9), 407-412. http://doi.org/10.17221/422/2018-pse.

Yi J, Gao JP, Zhang WZ, Zhao C, Wang Y, Zhen XX (2019) Differential uptake and utilization of two forms of nitrogen in japonica rice cultivars from north-eastern china. Frontiers in Plant Science, 10, 1061. http://doi.org/10.3389/fpls.2019.01061.

Yuan PL, Wang JP, Li CF, Cao CG (2020) Long-term rice-crayfish farming aggravate soil gleying and induced changes of soil iron morphology. Soil use and management, 1-14. https://doi.org/10.1111/sum.12688.

Yuan PL, Wang JP, Li CF, Xiao QQ, Liu QJ, Sun ZC, Wang JH, Cao CG (2020) Soil quality indicators of integrated rice-crayfish farming in the jianghan plain, china using a minimum data set. Soil and Tillage Research, 204, 104732. 10.1016/j.still.2020.104732.

Zhao GC, Hou LG, Cao Z, Zhao FJ, Sui PJ (2005) Study on the technology of rice-duck cocultivation. Jouurnal of Jilin Agricultural Sciences, 30(1):13-15. http://doi.org/10.16423/j.cnki.1003-8701.2005.01.004 (in Chinese).

Zhang J, Hu LL, Ren WZ, Guo L, Tang JJ, Shu MA, Chen X (2016) Rice-soft shell turtle coculture effects on yield and its environment. Agriculture, Ecosystems \& Environment, 224, 116122. http://dx.doi.org/10.1016/j.agee.2016.03.045. 


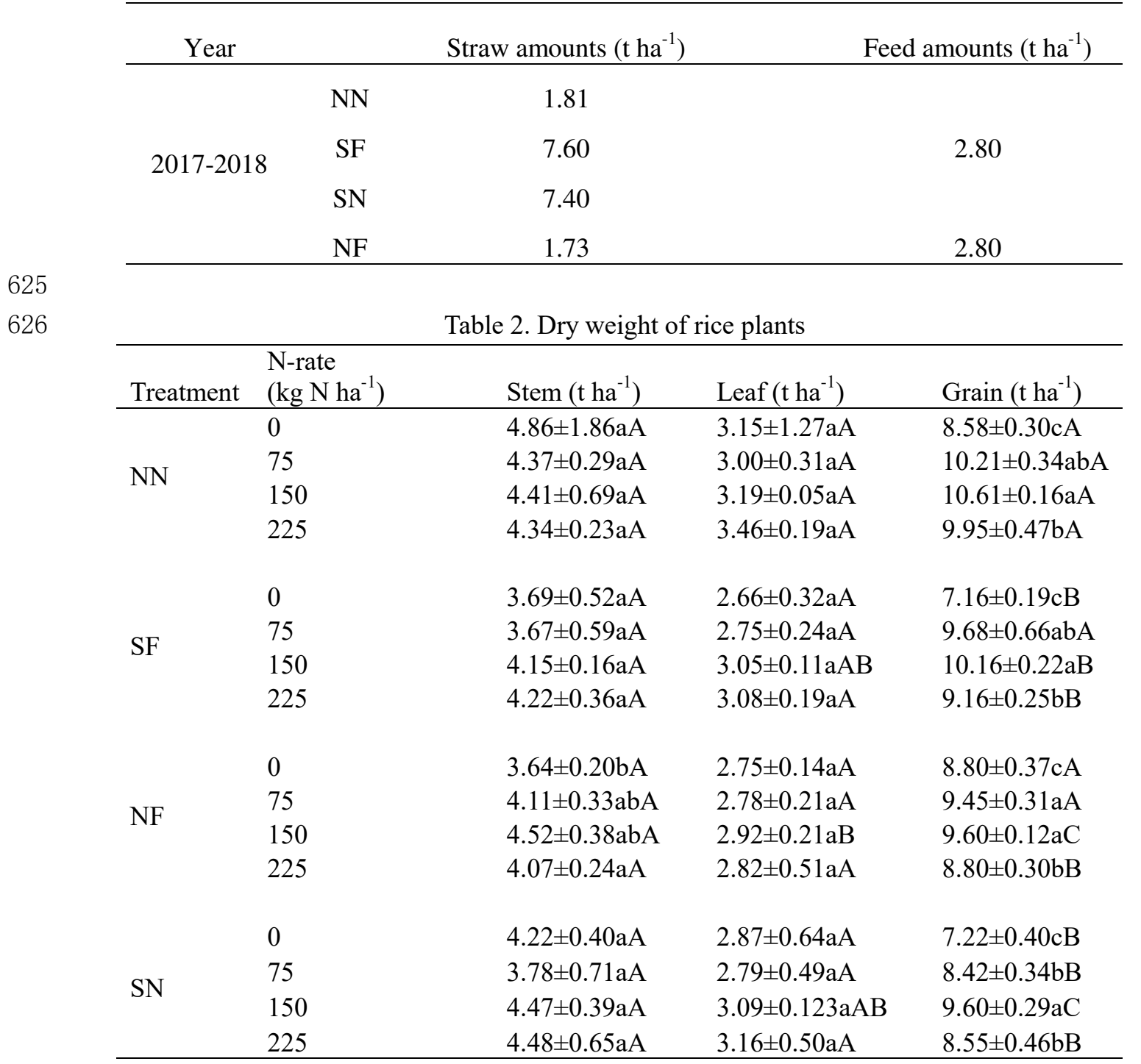

627 Note: Different capital letters represent significant differences at $p<0.05$ between different treatments 628 under the same nitrogen fertilizer level; different lowercase letters represent significant differences at $629 p<0.05$ under the same treatment and different nitrogen fertilizer levels. NN, no straw with no feed; SF, 630 straw with feed; SN, straw with no feed; NF, no straw with feed. All values are indicated as 631 means \pm standard deviation. 
Table $3 .{ }^{15} \mathrm{~N}$ Abundance and total nitrogen content in the rice plants in the mesocosm experiment

\begin{tabular}{|c|c|c|c|c|c|c|c|c|c|}
\hline \multirow{2}{*}{$\begin{array}{c}\text { N-rate } \\
\left(\mathrm{kg} \mathrm{N}^{-1}\right. \\
\left.\mathrm{ha}^{-1}\right)\end{array}$} & \multirow{2}{*}{$\begin{array}{l}\text { Rice } \\
\text { parts }\end{array}$} & \multicolumn{4}{|c|}{$\delta^{15} \mathrm{~N}$} & \multicolumn{4}{|c|}{ Total nitrogen content $(\mathrm{g} / \mathrm{kg})$} \\
\hline & & NN & $\mathrm{SF}$ & $\mathrm{NF}$ & $\mathrm{SN}$ & $\mathrm{NN}$ & $\mathrm{SF}$ & $\mathrm{NF}$ & $\mathrm{SN}$ \\
\hline \multirow{3}{*}{0} & Stem & $65 \pm 5 \mathrm{aB}$ & $72 \pm 9 \mathrm{bB}$ & $104 \pm 10 \mathrm{bA}$ & $116 \pm 6 a A$ & $6.42 \pm 0.58 \mathrm{aA}$ & $5.27 \pm 1.14 \mathrm{aAB}$ & $4.85 \pm 0.25 \mathrm{aB}$ & $6.42 \pm 0.50 \mathrm{aA}$ \\
\hline & Leaf & $74 \pm 6 \mathrm{aC}$ & $142 \pm 11 \mathrm{aB}$ & $228 \pm 38 \mathrm{aA}$ & $79 \pm 2 b C$ & $11.87 \pm 1.40 \mathrm{aB}$ & $10.54 \pm 1.56 \mathrm{aB}$ & $9.83 \pm 0.31 \mathrm{bB}$ & $14.92 \pm 1.41 \mathrm{aA}$ \\
\hline & Grain & $74 \pm 7 \mathrm{aB}$ & $121 \pm 2 \mathrm{aA}$ & $110 \pm 9 \mathrm{bA}$ & $59 \pm 3 \mathrm{bC}$ & $12.52 \pm 0.71 \mathrm{aAB}$ & $13.40 \pm 1.69 \mathrm{aA}$ & $11.12 \pm 0.70 \mathrm{aB}$ & $12.50 \pm 0.76 \mathrm{aAB}$ \\
\hline \multirow{3}{*}{75} & Stem & $2281 \pm 83 \mathrm{cA}$ & $2976 \pm 64 \mathrm{cA}$ & $2275 \pm 584 \mathrm{bA}$ & $2578 \pm 111 \mathrm{cA}$ & $5.81 \pm 0.25 \mathrm{aAB}$ & $6.00 \pm 0.55 \mathrm{aAB}$ & $5.23 \pm 0.47 \mathrm{aB}$ & $6.11 \pm 0.50 \mathrm{aA}$ \\
\hline & Leaf & $3096 \pm 248 \mathrm{cAB}$ & $3425 \pm 680 \mathrm{cA}$ & $2049 \pm 182 \mathrm{cA}$ & $2162 \pm 413 \mathrm{cB}$ & $10.50 \pm 0.73 \mathrm{aB}$ & $11.49 \pm 0.32 \mathrm{aB}$ & $10.61 \pm 0.56 \mathrm{bB}$ & $14.62 \pm 2.21 \mathrm{aA}$ \\
\hline & Grain & $2664 \pm 326 \mathrm{cA}$ & $2800 \pm 200 \mathrm{cA}$ & $1502 \pm 223 \mathrm{cB}$ & $1574 \pm 140 \mathrm{cB}$ & $12.19 \pm 0.33 \mathrm{aA}$ & $11.96 \pm 0.96 \mathrm{aA}$ & $10.71 \pm 1.53 \mathrm{aA}$ & $12.18 \pm 0.91 \mathrm{aA}$ \\
\hline \multirow{3}{*}{150} & Stem & $3803 \pm 594 \mathrm{bAB}$ & $4768 \pm 529 \mathrm{bA}$ & $3029 \pm 690 \mathrm{bB}$ & $4273 \pm 196 \mathrm{bA}$ & $5.91 \pm 0.49 \mathrm{aA}$ & $5.87 \pm 0.38 \mathrm{aA}$ & $5.00 \pm 0.33 \mathrm{aB}$ & $5.64 \pm 0.23 \mathrm{aAB}$ \\
\hline & Leaf & $5086 \pm 191 \mathrm{bB}$ & $6141 \pm 611 \mathrm{bA}$ & $3550 \pm 801 \mathrm{bC}$ & $4405 \pm 230 \mathrm{bBC}$ & $10.12 \pm 0.94 \mathrm{aA}$ & $11.21 \pm 0.01 \mathrm{aA}$ & $10.71 \pm 1.07 \mathrm{bA}$ & $11.56 \pm 3.89 \mathrm{aA}$ \\
\hline & Grain & $4712 \pm 120 \mathrm{bA}$ & $4826 \pm 376 \mathrm{bA}$ & $2881 \pm 213 b C$ & $4089 \pm 220 \mathrm{bB}$ & $12.08 \pm 1.36 \mathrm{aA}$ & $13.40 \pm 1.51 \mathrm{aA}$ & $12.08 \pm 0.49 \mathrm{aA}$ & $11.87 \pm 0.64 \mathrm{aA}$ \\
\hline \multirow{3}{*}{225} & Stem & $6667 \pm 777 \mathrm{aA}$ & $6155 \pm 539 \mathrm{aAB}$ & $5273 \pm 423 \mathrm{aB}$ & $5772 \pm 40 \mathrm{aAB}$ & $6.38 \pm 0.49 \mathrm{aA}$ & $5.39 \pm 0.98 \mathrm{aA}$ & $5.33 \pm 0.68 \mathrm{aA}$ & $6.31 \pm 0.56 \mathrm{aA}$ \\
\hline & Leaf & $6683 \pm 330 \mathrm{aAB}$ & $7652 \pm 720 \mathrm{aA}$ & $5707 \pm 948 \mathrm{aB}$ & $6100 \pm 340 \mathrm{aB}$ & $11.04 \pm 1.11 \mathrm{aA}$ & $10.21 \pm 1.14 \mathrm{aA}$ & $13.58 \pm 1.36 \mathrm{aA}$ & $13.18 \pm 3.12 \mathrm{aA}$ \\
\hline & Grain & $6174 \pm 71 \mathrm{aA}$ & $6031 \pm 576 \mathrm{aAB}$ & $4288 \pm 12.42 \mathrm{aC}$ & $5493 \pm 265 \mathrm{aB}$ & $11.91 \pm 1.35 \mathrm{aA}$ & $11.64 \pm 0.51 \mathrm{aA}$ & $12.7 \pm 2.01 \mathrm{aA}$ & $11.82 \pm 0.61 \mathrm{aA}$ \\
\hline
\end{tabular}

639 Note: Different capital letters represent significant differences at $p<0.05$ between different treatments

640 under the same nitrogen fertilizer level; different lowercase letters represent significant differences at

$641 p<0.05$ under the same treatment and different nitrogen fertilizer levels. All values are indicated as

642 means \pm standard deviation.

643

Table 4. $\mathrm{N}$ accumulation in crayfish.

\begin{tabular}{|c|c|c|c|c|c|c|c|c|c|c|c|c|}
\hline & NN & & & SF & & & SN & & & NF & & \\
\hline Wet weight(g) & 54.1 & \pm & $26.4 \mathrm{a}$ & 78.9 & \pm & $14.5 \mathrm{a}$ & 80.0 & \pm & $33.1 \mathrm{a}$ & 73.7 & \pm & $35.6 \mathrm{a}$ \\
\hline Dry weight(g) & 13.9 & \pm & $7.6 \mathrm{a}$ & 21.7 & \pm & $5.7 \mathrm{a}$ & 20.0 & \pm & $9.9 \mathrm{a}$ & 21.1 & \pm & $12.0 \mathrm{a}$ \\
\hline water content $(\%)$ & 0.7 & \pm & $0.0 \mathrm{a}$ & 0.7 & \pm & $0.0 \mathrm{a}$ & 0.8 & \pm & $0.0 \mathrm{a}$ & 0.7 & \pm & $0.0 \mathrm{a}$ \\
\hline $\mathrm{TN}\left(\mathrm{g} \mathrm{kg}^{-1}\right)$ & 6.9 & \pm & $0.4 \mathrm{a}$ & 6.6 & \pm & $0.4 \mathrm{a}$ & 6.4 & \pm & $0.7 \mathrm{a}$ & 6.4 & \pm & $0.9 \mathrm{a}$ \\
\hline $\begin{array}{l}\text { Crayfish yield } \\
\left(\mathrm{t} \mathrm{ha}^{-1}\right)\end{array}$ & 0.6 & \pm & $0.02 \mathrm{c}$ & 1.2 & \pm & $0.03 a$ & 0.7 & \pm & $0.01 b$ & 1.1 & \pm & $0.05 \mathrm{a}$ \\
\hline $\begin{array}{l}\text { Crayfish-N } \\
\left(\mathrm{kg} \mathrm{ha}^{-1}\right)\end{array}$ & 4.4 & \pm & $0.2 \mathrm{c}$ & 7.9 & \pm & $0.6 \mathrm{a}$ & 4.5 & \pm & $0.3 \mathrm{c}$ & 7.0 & \pm & $0.8 \mathrm{~b}$ \\
\hline
\end{tabular}

645 Note: Different lowercase letters represent significant differences at $p<0.05$ between different

646 treatments. All values are indicated as means \pm standard deviation.

647

648

Table 5. Total nitrogen and ${ }^{15} \mathrm{~N}\left(\mathrm{~g} \mathrm{~kg}^{-1}\right)$ content in soil

\begin{tabular}{|c|c|c|c|c|c|c|c|c|}
\hline \multirow{2}{*}{$\begin{array}{l}\text { N rate } \\
\left(\mathrm{kg} \mathrm{ha}^{-1}\right)\end{array}$} & \multicolumn{4}{|c|}{$\mathrm{TN}$} & \multicolumn{4}{|c|}{${ }^{15} \mathrm{~N}$} \\
\hline & $\mathrm{NN}$ & $\mathrm{SF}$ & $\mathrm{SN}$ & $\mathrm{NF}$ & $\mathrm{NN}$ & $\mathrm{SF}$ & SN & $\mathrm{NF}$ \\
\hline 75 & $2.78 \pm 0.04 \mathrm{aB}$ & $3.00 \pm 0.12 \mathrm{aA}$ & $2.97 \pm 0.10 \mathrm{aA}$ & $2.97 \pm 0.23 \mathrm{aA}$ & $0.97 \pm 0.10 \mathrm{cA}$ & $1.08 \pm 0.11 \mathrm{cA}$ & $0.73 \pm 0.17 \mathrm{cB}$ & $1.20 \pm 0.12 \mathrm{bA}$ \\
\hline 150 & $2.82 \pm 0.15 \mathrm{aB}$ & $3.07 \pm 0.10 \mathrm{aA}$ & $3.00 \pm 0.02 \mathrm{aA}$ & $2.96 \pm 0.08 \mathrm{aA}$ & $2.11 \pm 0.19 \mathrm{bA}$ & $1.47 \pm 0.13 \mathrm{bB}$ & $1.38 \pm 0.19 \mathrm{bB}$ & $1.18 \pm 0.12 \mathrm{bC}$ \\
\hline 225 & $2.83 \pm 0.13 \mathrm{aB}$ & $3.01 \pm 0.02 \mathrm{aA}$ & $3.24 \pm 0.37 \mathrm{aA}$ & $3.20 \pm 0.19 \mathrm{aA}$ & $2.36 \pm 0.09 \mathrm{aA}$ & $2.09 \pm 0.13 \mathrm{aA}$ & $2.40 \pm 0.30 \mathrm{aA}$ & $2.27 \pm 0.15 \mathrm{aA}$ \\
\hline
\end{tabular}

649 Different capital letters represent significant differences at $p<0.05$ between different treatments

650 under the same nitrogen fertilizer level; different lowercase letters represent significant differences

651 at $p<0.05$ under the same treatment and different nitrogen fertilizer levels. All values are indicated 
653

654 Table 6. Nitrogen use efficiency under different rates of nitrogen application

\begin{tabular}{|c|c|c|c|c|c|c|c|c|c|}
\hline \multirow{2}{*}{$\begin{array}{l}\text { Plant } \\
\text { part }\end{array}$} & \multirow{2}{*}{$\begin{array}{c}\mathrm{N} \text { rate } \\
\left(\begin{array}{c}\mathrm{kg} \mathrm{N} \\
1 \\
1\end{array}\right)\end{array}$} & \multicolumn{4}{|c|}{$\mathrm{N}_{\mathrm{dff}}$} & \multicolumn{4}{|c|}{ NUE(\%) } \\
\hline & & $\mathrm{NN}$ & SF & $\mathrm{NF}$ & SN & $\mathrm{NN}$ & SF & $\mathrm{NF}$ & SN \\
\hline \multirow{3}{*}{ Stem } & 75 & $8.8 \pm 0.3 \mathrm{Ac}$ & $11.5 \pm 0.3 \mathrm{Ac}$ & $8.5 \pm 2.3 \mathrm{Ab}$ & $9.8 \pm 4.4 \mathrm{Ac}$ & $3.0 \pm 0.3 \mathrm{Aa}$ & $3.4 \pm 0.5 \mathrm{Aa}$ & $2.5 \pm 0.8 \mathrm{Aa}$ & $2.9 \pm 0.9 \mathrm{Aa}$ \\
\hline & 150 & $14.8 \pm 2.4 \mathrm{ABb}$ & $18.6 \pm 2.1 \mathrm{Ab}$ & $11.5 \pm 2.7 \mathrm{Bb}$ & $16.5 \pm 0.8 \mathrm{ABb}$ & $2.6 \pm 0.5 \mathrm{ABa}$ & $3.0 \pm 0.4 \mathrm{Aa}$ & $1.8 \pm 0.6 \mathrm{Ba}$ & $2.8 \pm 0.4 \mathrm{Aa}$ \\
\hline & 225 & $26.1 \pm 3.1 \mathrm{Aa}$ & $24.0 \pm 2.1 \mathrm{ABa}$ & $20.4 \pm 1.7 \mathrm{Ba}$ & $22.4 \pm 0.2 \mathrm{ABa}$ & $3.2 \pm 0.3 \mathrm{Aa}$ & $2.5 \pm 0.8 \mathrm{ABa}$ & $2.0 \pm 0.3 \mathrm{Ba}$ & $2.8 \pm 0.6 \mathrm{ABa}$ \\
\hline \multirow{3}{*}{ Leaf } & 75 & $12.0 \pm 1.0 \mathrm{Ac}$ & $13.0 \pm 2.7 \mathrm{Ac}$ & $7.3 \pm 0.7 \mathrm{Bc}$ & $8.2 \pm 1.6 \mathrm{Bc}$ & $5.1 \pm 1.1 \mathrm{Aa}$ & $5.5 \pm 1.5 \mathrm{Aa}$ & $2.9 \pm 0.5 \mathrm{Ba}$ & $4.4 \pm 1.0 \mathrm{ABa}$ \\
\hline & 150 & $20.0 \pm 0.8 \mathrm{Bb}$ & $23.8 \pm 2.4 \mathrm{Ab}$ & $13.2 \pm 3.2 \mathrm{Cb}$ & $17.1 \pm 0.9 \mathrm{Bb}$ & $4.3 \pm 0.5 \mathrm{ABa}$ & $5.5 \pm 0.7 \mathrm{Aa}$ & $2.8 \pm 0.9 \mathrm{Ba}$ & $4.1 \pm 1.5 \mathrm{ABa}$ \\
\hline & 225 & $26.0 \pm 1.3 \mathrm{ABa}$ & $30.0 \pm 2.9 \mathrm{Aa}$ & $21.8 \pm 3.8 \mathrm{Ba}$ & $23.9 \pm 1.3 \mathrm{Ba}$ & $4.4 \pm 0.4 \mathrm{Aa}$ & $4.1 \pm 0.5 \mathrm{Aa}$ & $3.6 \pm 0.4 \mathrm{Aa}$ & $4.3 \pm 0.6 \mathrm{Aa}$ \\
\hline \multirow{3}{*}{ Grain } & 75 & $10.0 \pm 1.3 \mathrm{Ac}$ & $10.6 \pm 0.8 \mathrm{Ac}$ & $5.5 \pm 0.9 \mathrm{Bc}$ & $6.0 \pm 0.6 \mathrm{Bc}$ & $17.0 \pm 2.0 \mathrm{Aa}$ & $16.4 \pm 1.3 \mathrm{Aa}$ & $7.5 \pm 2.1 \mathrm{Ba}$ & $8.2 \pm 1.2 \mathrm{Bb}$ \\
\hline & 150 & $18.1 \pm 0.5 \mathrm{Ab}$ & $18.7 \pm 1.5 \mathrm{Ab}$ & $11.0 \pm 0.8 \mathrm{Bb}$ & $15.9 \pm 0.9 \mathrm{Cb}$ & $15.7 \pm 2.2 \mathrm{Aab}$ & $16.9 \pm 1.3 \mathrm{Aa}$ & $8.5 \pm 0.7 \mathrm{Ca}$ & $12.1 \pm 0.4 \mathrm{Ba}$ \\
\hline & 225 & $24.2 \pm 0.3 \mathrm{Aa}$ & $23.4 \pm 2.3 \mathrm{ABa}$ & $16.6 \pm 1.1 \mathrm{Ca}$ & $21.5 \pm 1.0 \mathrm{Ba}$ & $12.7 \pm 1.7 \mathrm{Ab}$ & $11.1 \pm 1.6 \mathrm{ABb}$ & $7.8 \pm 0.7 \mathrm{Ca}$ & $9.6 \pm 0.5 \mathrm{Bb}$ \\
\hline \multirow{3}{*}{ Total } & 75 & $31.2 \pm 0.5 \mathrm{Ac}$ & $35.2 \pm 3.6 \mathrm{Ac}$ & $21.3 \pm 3.7 \mathrm{Bc}$ & $24.0 \pm 5.2 \mathrm{Bc}$ & $25.0 \pm 0.8 \mathrm{Aa}$ & $25.2 \pm 2.6 \mathrm{Aa}$ & $12.9 \pm 3.4 \mathrm{Ba}$ & $15.5 \pm 1.1 \mathrm{Bb}$ \\
\hline & 150 & $53.0 \pm 1.7 \mathrm{ABb}$ & $61.1 \pm 5.5 \mathrm{Ab}$ & $35.8 \pm 6.7 \mathrm{Cb}$ & $49.6 \pm 0.7 \mathrm{Bb}$ & $22.6 \pm 1.6 \mathrm{ABab}$ & $25.3 \pm 2.1 \mathrm{Aa}$ & $13.1 \pm 2.1 \mathrm{Ca}$ & $19.0 \pm 1.9 \mathrm{Ba}$ \\
\hline & 225 & $76.2 \pm 4.6 \mathrm{Aa}$ & $77.4 \pm 4.9 \mathrm{Aa}$ & $58.8 \pm 6.1 \mathrm{Ca}$ & $67.8 \pm 0.9 \mathrm{Ba}$ & $20.4 \pm 1.5 \mathrm{Ab}$ & $17.8 \pm 2.3 \mathrm{ABb}$ & $13.4 \pm 0.5 \mathrm{Ca}$ & $16.8 \pm 1.6 \mathrm{Bab}$ \\
\hline
\end{tabular}

655 Note: Different capital letters represent significant differences $(p<0.05)$ between different treatments

656 under the same nitrogen fertilizer application rates; different lowercase letters represent significant

657 differences $(p<0.05)$ under the same treatment but different nitrogen fertilizer application rates. All

658 values are indicated as means \pm standard deviation.

659

660

Table 7. Soil bulk density $\left(\mathrm{g} \mathrm{cm}^{-3}\right)$ in the mesocosm experiment

\begin{tabular}{ccccc}
\hline $\begin{array}{c}\text { N rate } \\
(\mathrm{kg} \mathrm{Nha}\end{array}$ & $\mathrm{NN}$ & $\mathrm{SF}$ & $\mathrm{SN}$ & $\mathrm{NF}$ \\
\hline 75 & $1.17 \pm 0.09 \mathrm{aA}$ & $1.05 \pm 0.06 \mathrm{aA}$ & $1.14 \pm 0.07 \mathrm{aA}$ & $1.13 \pm 0.12 \mathrm{aA}$ \\
150 & $1.11 \pm 0.02 \mathrm{aA}$ & $1.07 \pm 0.03 \mathrm{aA}$ & $1.09 \pm 0.10 \mathrm{aA}$ & $1.03 \pm 0.10 \mathrm{aA}$ \\
225 & $1.14 \pm 0.10 \mathrm{aA}$ & $1.17 \pm 0.07 \mathrm{aA}$ & $1.17 \pm 0.06 \mathrm{~A}$ & $1.21 \pm 0.08 \mathrm{aA}$ \\
\hline
\end{tabular}

661 Note: Different capital letters represent significant differences at $p<0.05$ between different treatments

662 under the same nitrogen fertilizer level; different lowercase letters represent significant differences at

$663 p<0.05$ under the same treatment and different nitrogen fertilizer levels. All values are indicated as

664 means \pm standard deviation.

665

666

667

668

669 
671 Fig. 1. Changes in daily temperature and rainfall at the experimental sites in 2018.

672 Red, green, and blue represent the maximum temperature, minimum temperature, and

673 rainfall, respectively.

674 Fig. 2. Pie charts showing the proportion of nitrogen derived from crayfish feed in harvested rice, harvested crayfish, and the environment (e.g., 13.6\% of the $\mathrm{N}$ supplied by crayfish feed was estimated to be present in the RC system) and the proportion of nitrogen derived from straw in harvested rice, harvested crayfish, and the environment in the RC system (e.g., $4.3 \%$ of the nitrogen supplied by straw was estimated to be contained in the $\mathrm{RC}$ system) under different nitrogen application conditions. (a) $0 \mathrm{~kg}$ $\mathrm{N}^{-1}$ level, (b) $75 \mathrm{~kg} \mathrm{~N}^{-1}$ level, (c) $150 \mathrm{~kg} \mathrm{~N}^{-1}$ level, and (d) $225 \mathrm{~kg} \mathrm{~N} \mathrm{ha}^{-1}$ level. The calculations for the balance of nitrogen output and input within the RC system are described in the Materials and methods section 2.4.1. The calculations used to determine the fate of feed-N and straw-N are described in the Materials and methods section 2.4.2.

Fig. 3. Flow direction of fertilizer nitrogen. Different capital letters represent significant differences $(p<0.05)$ between different treatments under the same nitrogen fertilizer application rates; different lowercase letters represent significant differences $(p<0.05)$ under the same treatment but different nitrogen fertilizer application rates. The labels 75,150 , and 225 on the $\mathrm{X}$-axis represent the nitrogen application rates of $75 \mathrm{~kg} \mathrm{ha}^{-1}, 150 \mathrm{~kg} \mathrm{ha}^{-1}$, and $225 \mathrm{~kg} \mathrm{ha}^{-1}$, respectively. NN, no straw with no feed; SF, straw with feed; SN, straw with no feed; NF, no straw with feed. Error bars represent the standard deviation. NUE (\%), the percentage of the nitrogen in the fertilizer absorbed and utilized by rice plants; Rsoil (\%), the percentage of the nitrogen in the fertilizer stored in the soil; Rloss (\%), the percentage of the nitrogen in the fertilizer lost to the environment.

Fig. 4. Nitrogen storage in rice grains, leaves, and stems; crayfish; and the environment in a field experiment in which the rice-crayfish (RC) system was subjected to different nitrogen application conditions. (a) $0 \mathrm{~kg} \mathrm{~N} \mathrm{ha}^{-1}$ level, (b) $75 \mathrm{~kg}$ $\mathrm{N} \mathrm{ha}^{-1}$ level, (c) $150 \mathrm{~kg} \mathrm{~N} \mathrm{ha}^{-1}$ level, and (d) $225 \mathrm{~kg} \mathrm{~N}^{-1}$ level. Values are means \pm $\mathrm{SD}$. A negative mean for environmental nitrogen indicates that rice and/or crayfish, in addition to obtaining $\mathrm{N}$ from feed, obtained $\mathrm{N}$ from environmental sources. A positive value for environmental $\mathrm{N}$ indicates that $\mathrm{N}$ was lost to the environment. $\mathrm{NN}$, no straw with no feed; SF, straw with feed; SN, straw with no feed; NF, no straw with feed. 


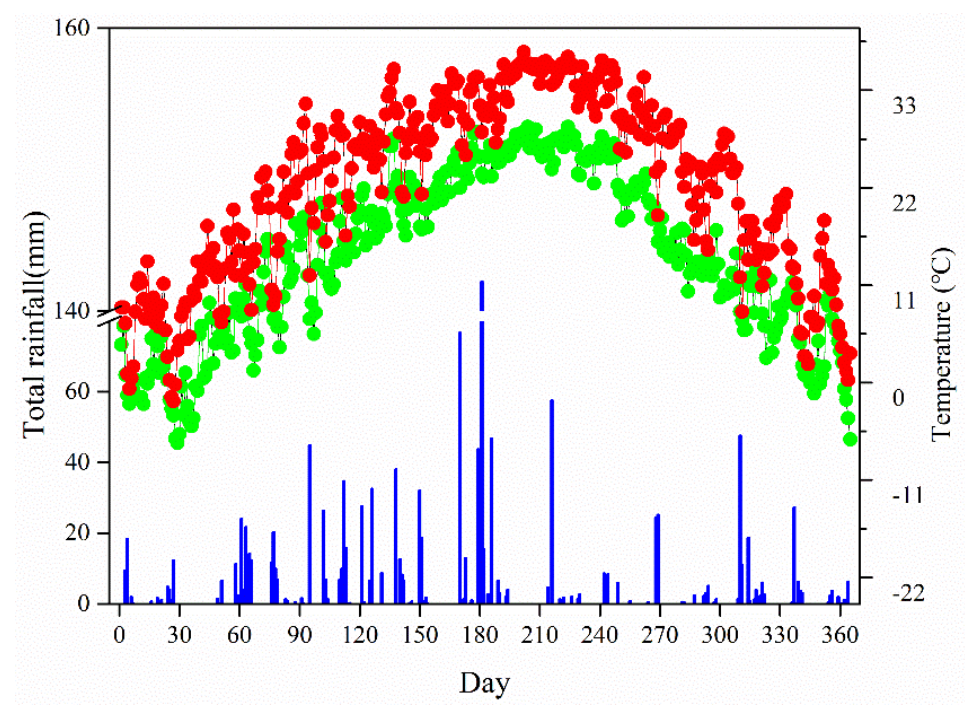



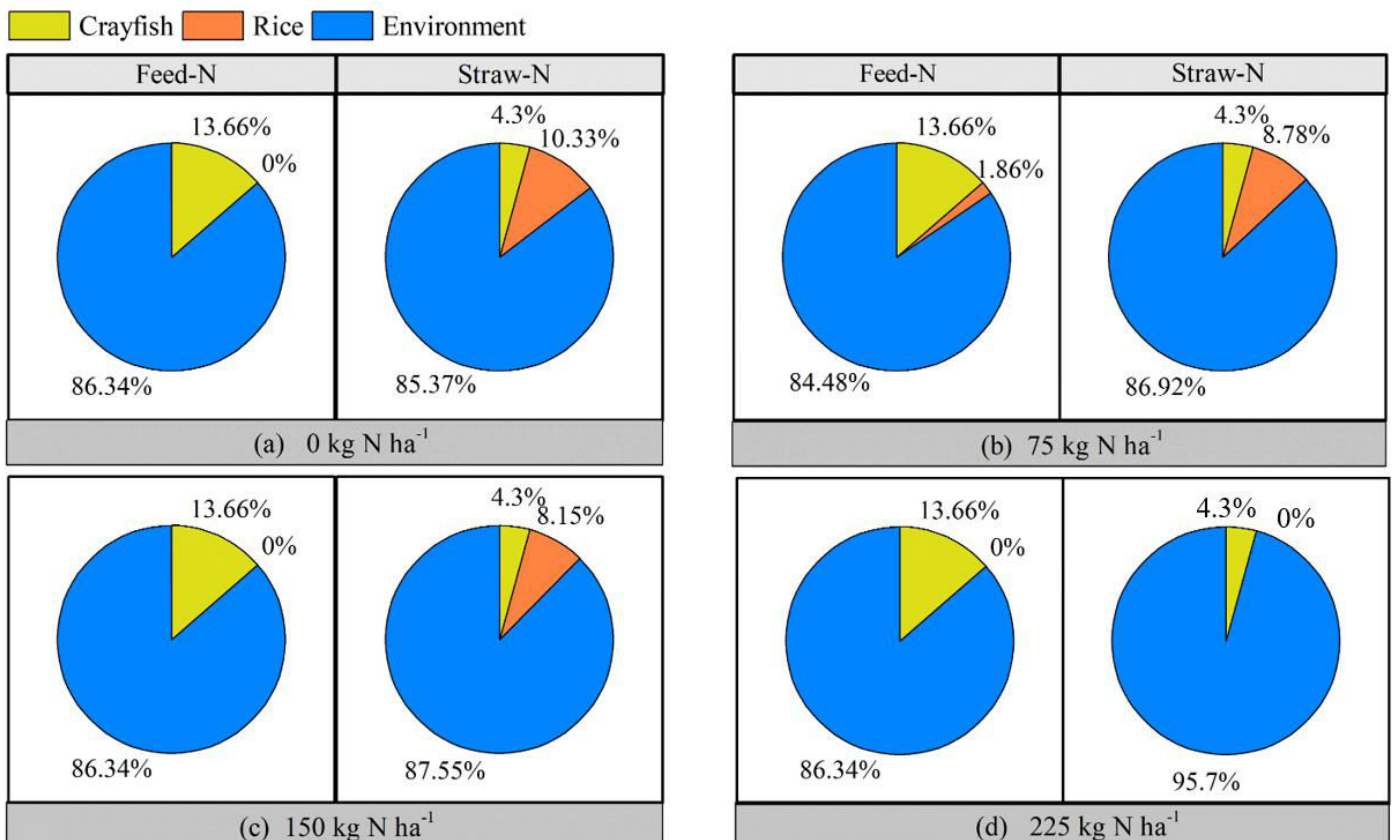

(b) $75 \mathrm{~kg} \mathrm{~N}^{-1}$

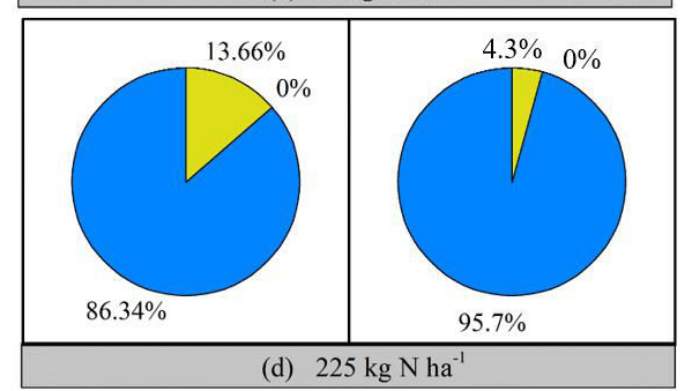




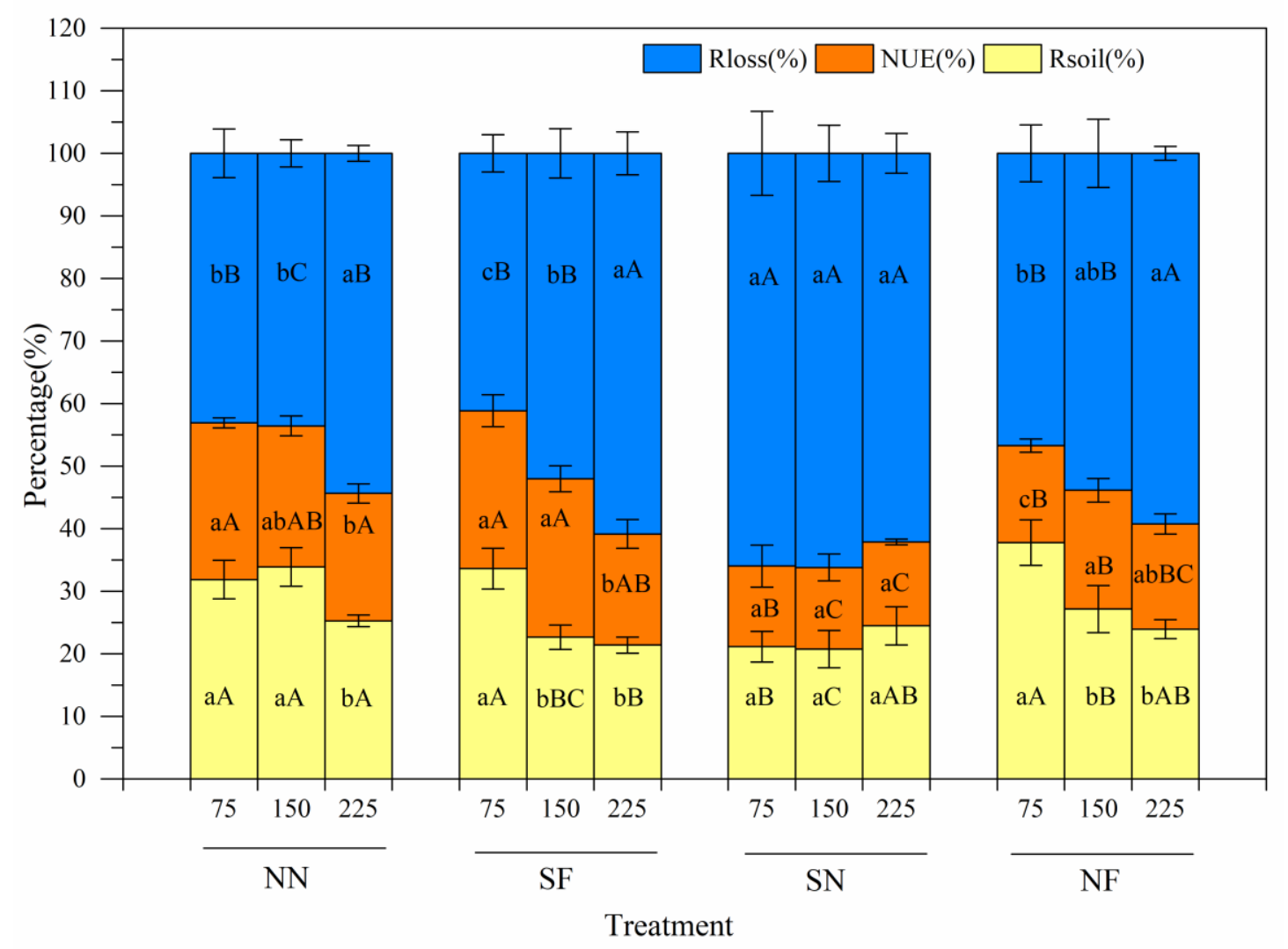



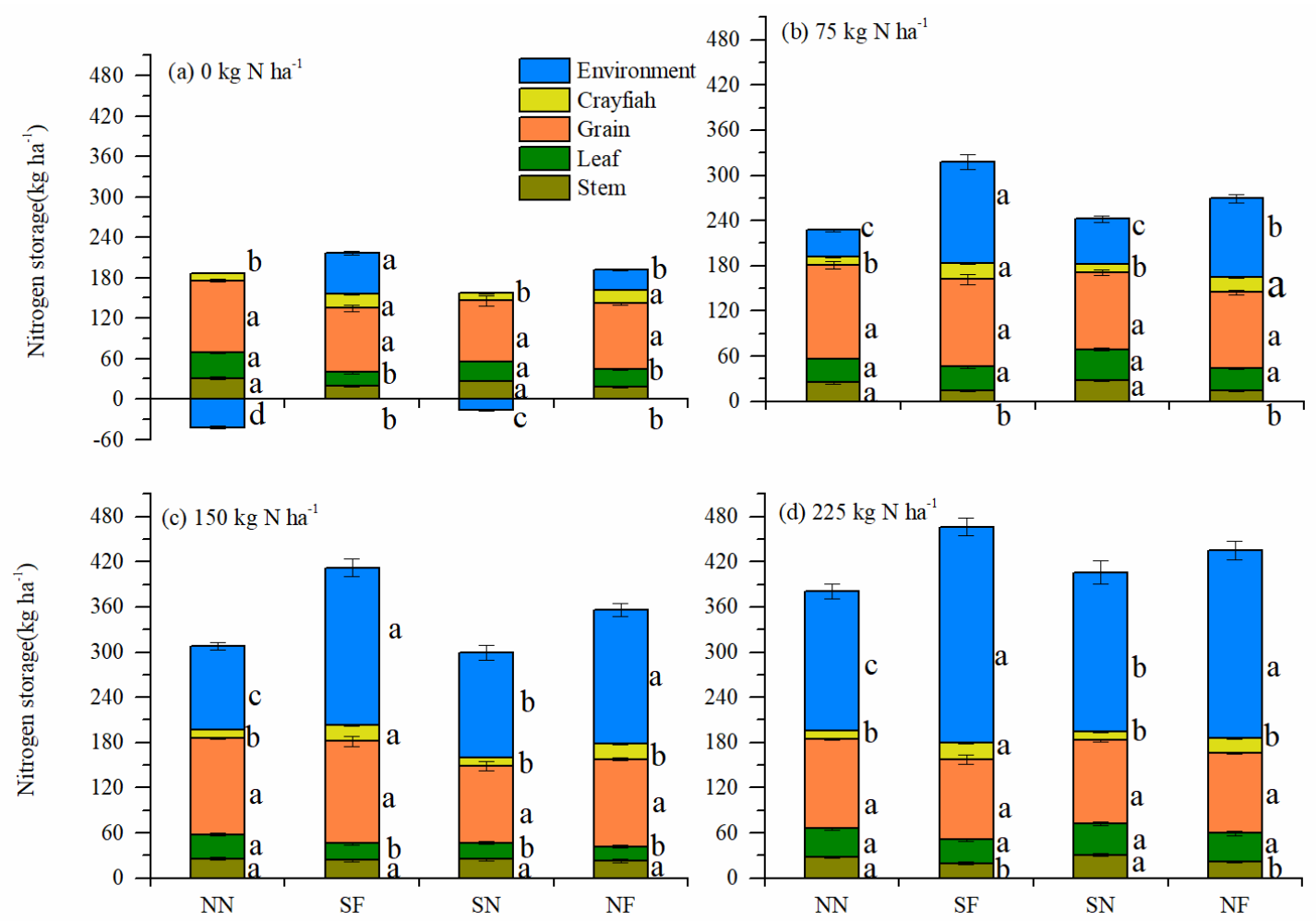